\title{
Cestoda, Bothriocephalidae, Bothriocephalus acheilognathi Yamaguti, 1934; Nematoda, Rhabdochonidae, Rhabdochona canadensis Moravec and Arai, 1971: New records for the state of Puebla, Mexico, and a new fish host
}

\author{
Rogelio Aguilar-Aguilar ${ }^{1 *}$, Alexis José-Abrego ${ }^{2}$ and Gerardo Pérez-Ponce de León ${ }^{3}$ \\ 1 Universidad Nacional Autónoma de México, Facultad de Ciencias, Departamento de Biología Comparada. Ap. Postal 70-399. C.P. 04510. México \\ D.F., Mexico. \\ 2 Universidad Autónoma “Benito Juárez” de Oaxaca, Escuela de Ciencias. Av. Universidad s/n, ExHacienda de 5 señores. CP 68120.0 axaca, Mexico. \\ 3 Universidad Nacional Autónoma de México, Instituto de Biología, Laboratorio de Helmintología, Ap. Postal 70-153. C.P. 04510. México D. F., \\ Mexico. \\ * Corresponding author. E-mail: raguilar@ibiologia.unam.mx
}

\begin{abstract}
In order to contribute to the knowledge on helminth parasites of freshwater fishes in Mexico, the helminth fauna of the cyprinid fish Notropis moralesi was studied. The helminth species Bothriocephalus acheilognathi and Rhabdochona canadensis were recovered from 20 examined hosts. Values of prevalence, abundance and mean intensity of each infection are provided. Present work represents the first helminthological study for $N$. moralesi. Therefore, both helminth species recorded are new host records. This is the second report of B. acheilognathi and the first of $R$. canadensis for the state of Puebla.
\end{abstract}

Freshwater fishes represent the host group with the largest study effort for helminth parasites among vertebrates in Mexico (Pérez-Ponce de León and Choudhury 2010). It has been argued that the inventory of the helminth fauna of these hosts is nearing completion and because of that it has been suggested that sampling effort must be focused to discover the missing component of the host spectrum (Pérez-Ponce de León and Choudhury 2010), and that included, particular regions in the country and certain hosts groups such as cyprinids. In this context, this note provide the first study on the helminth fauna of the freshwater fish Notropis moralesi De Buen, 1955 (Cyprinidae) in Puebla state, central Mexico, a region of the country that has been scarcely studied for helminth parasites.

During a prospective study addressed to establish the parasitological fauna of freshwater fishes occurring in river basins along central Mexico, twenty individuals of $N$. moralesi were examined for helminth parasites. Fishes (collected under the Cartilla Nacional de Colector Científico de Flora y Fauna Silvestre FAUT-0057 issued to G.P.P.L.) were captured on April 2009 in the Ahuehuello River at Santo Domingo Ayotlicha, an affluent of the Balsas River Basin (1843'12.5” N, 98³4'43.4" W), using an electrofishing device. Individual fishes were kept alive and studied for helminths no more that 6 hours after capture. All internal organs were analyzed separately in Petri dishes with $0.65 \%$ saline under the stereomicroscope. Parasites were removed to a Petri dish with saline $0.65 \%$, prior to fixation. Cestodes were fixed with hot (steaming) $4 \%$ formalin, while nematodes were fixed with hot (steaming) $4 \%$ formalin or $70 \%$ ethanol. All helminths were processed following standard procedures. Identification was made using specialized literature, and representative specimens of the helminth species were deposited at the Colección Nacional de Helmintos, Instituto de Biología, Universidad Nacional Autónoma de México (UNAM), Mexico City (CNHE).

Two helminth species were found in the examined hosts: the anthropogenically introduced cestode Bothriocephalus acheilognathi Yamaguti, 1934 (47 individuals, prevalence $60 \%$, abundance $2.35 \pm 2.74$, mean intensity $3.9 \pm 2.5$ worms per infected host), and the nematode Rhabdochona canadensis Moravec and Arai, 1971 (Figure 1, 135 individuals, prevalence $90 \%$, abundance $6.75 \pm 6.72$, mean intensity $7.5 \pm 6.7$ worms per infected host). No larval stages of any helminth species were found. Only 1 host in the sample was free of infection.

The cestode $B$. acheilognathi is a generalist species commonly recorded in freshwater fishes in Mexico (Salgado-Maldonado and Pineda-López 2003; Okoldkov et al. 2007). This species was introduced into Mexico along with its hosts, common carps, from Asia. It possesses a large dispersal capability and it is now found not only in introduced hosts but also in the native freshwater fish fauna (Pérez-Ponce de León et al. 2009). Previous records of this cestode in fishes of the genus Notropis Rafinesque in Mexico includes its finding in the species $N$. chihuahua Woolman and N. nazas Meek from the Nazas River basin, Durango state, North of Mexico (Pérez-Ponce de León et al. 2010). The record of $B$. acheilognathi established herein represents the second for Puebla state, Mexico, where it was previously found in Poecilia sp. (Aguilar-Aguilar et al. 2004). 
Nematodes of the species $R$. canadensis have frequently been reported for freshwater fish species, mainly belonging to the family Cyprinidae, in North America (Hoffman 1999; Caspeta-Mandujano 2005; Garrido-Olvera et al. 2006). Studies on the seasonal dynamics of this nematode conducted in central Mexico suggest that its prevalence and mean intensity in hosts of the genus Notropis fluctuate throughout the year, occurring an increase for these parameters in some seasons (Caspeta-Mandujano and Mejía-Mojica 2004). Previous records of this nematode in species of Notropis in Mexico includes Notropis sp., and N. boucardi (Günther) from Guerrero, Hidalgo, Estado de México, Michoacán, Morelos and Oaxaca states in central Mexico (Caspeta-Mandujano 2005; Garrido-Olvera et al. 2006), and N. chihuahua and N. nazas from the Nazas River basin, Durango state, North of Mexico (Pérez-Ponce de León et al. 2010). The present is the first record of this nematode in freshwater fishes of Puebla state in central Mexico.

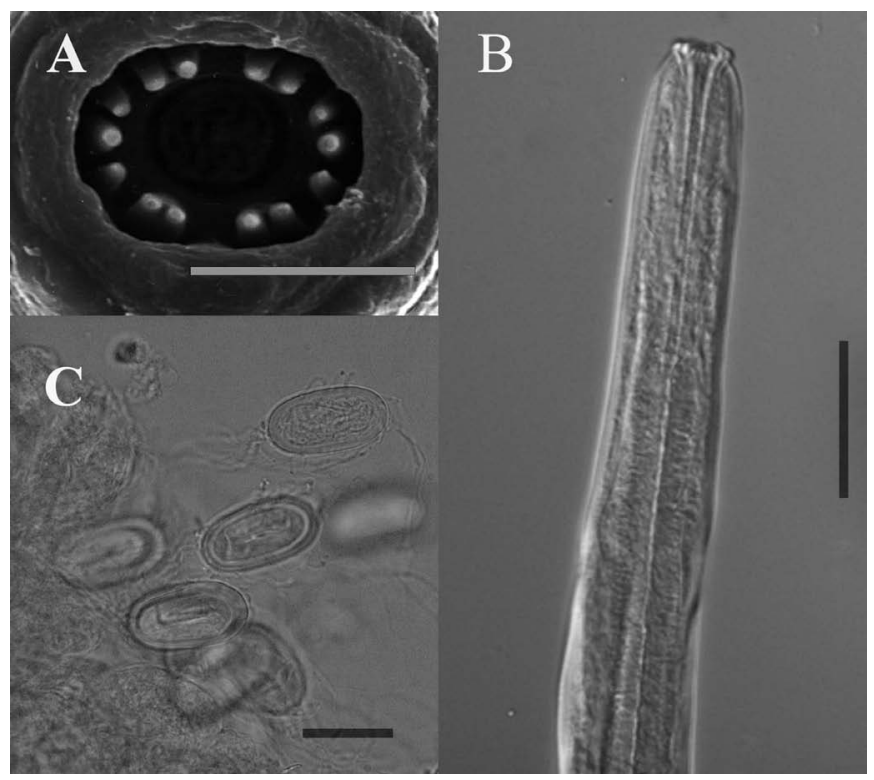

FiguRE 1. Rhabdochona canadensis. A, Anterior end of male, apical view (x 10k), scale bar $5 \mu \mathrm{m}$; B, Anterior end of female, scale bar $0.05 \mathrm{~mm}$; C, Detail of mature, larvated and filamented eggs, scale bar $0.03 \mathrm{~mm}$.
ACKNOWLEDGMents: We thank Andrés Martínez Aquino and Rodolfo Pérez Rodríguez for technical assistance in field and laboratory. Rodolfo Pérez Rodríguez realized the taxonomic determination of the host. Thanks also due to Berenit Mendoza Garfias for the SEM picture. This project was funded by the Consejo Nacional de Ciencia y Tecnología (CONACyT 83043), and Programa de Apoyo a Proyectos de Investigación e Innovación Tecnológica (PAPIIT-UNAM IN 209608) to G.P.P.L.

\section{Literature Cited}

Aguilar-Aguilar, R., G. Salgado-Maldonado, R.G. Moreno-Navarrete and G. Cabañas-Carranza. 2004. Helmintos parásitos de peces dulceacuícolas; p. 261-270 In Luna, I., J. J. Morrone and D. Espinosa (ed.). Biodiversidad de la Sierra Madre Oriental. México: UNAM, Facultad de Ciencias.

Caspeta-Mandujano, J.M. 2005. Nematodes parasites of freshwater fish in Mexico: Key to species, descriptions and distribution. Cuernavaca: Universidad Autónoma del Estado de Morelos. 175 p.

Caspeta-Mandujano, J.M. and H. Mejía-Mojica. 2004. Seasonal dynamics of the occurrence and maturation of Rhabdochona canadensis in its definitive host, Notropis boucardi, of the Chalma River, State of Morelos, Mexico. Helminthologia 41(3): 121-123.

Garrido-Olvera, L., L. García-Prieto and G. Pérez-Ponce de León. 2006 Checklist of the adult nematode parasites of fishes in freshwater localities from Mexico. Zootaxa 1201: 1-45.

Hoffman, G.L. 1999. Parasites of North American freshwater fishes. 2ND Edition. Ithaca: Cornell University Press. 539 p.

Okolodkov Y.B., R. Bastida-Zavala, A.L. Ibáñez, J.W. Chapman, E. SuárezMorales, F. Pedroche and F.J. Gutiérrez-Mendieta. 2007. Especies acuáticas no indígenas en México. Ciencia y Mar 11 (32): 29-67.

Pérez-Ponce de León, G. and A. Choudhury. 2010. Parasite Inventories and DNA-based taxonomy: Lessons from helminths of freshwater fishes in a megadiverse country. Journal of Parasitology 96(1): 236-244.

Pérez-Ponce de León, G., R. Rosas-Valdez, R. Aguilar-Aguilar, B. MendozaGarfias, C. Mendoza-Palmero, L. García-Prieto, A. Rojas-Sánchez, R. Briosio-Aguilar, R. Pérez Rodríguez and O. Domínguez-Domínguez. 2010. Helminth parasites of freshwater fishes, Nazas River basin, northern Mexico. Check List 6(1): 26-35.

Pérez-Ponce de León, G., R. Rosas-Valdez, B. Mendoza-Garfias, R. AguilarAguilar, J. Falcón-Ordaz, L. Garrido-Olvera and R. Pérez-Rodríguez. 2009. Survey of endohelminth parasites of freshwater fishes in the upper Mezquital River basin, Durango state, Mexico. Zootaxa 2164: $1-20$.

Salgado-Maldonado, G. and R.F. Pineda-López. 2003. The Asian fish tapeworm Bothriocephalus acheilognathi: A potential threat to native freshwater fish species in Mexico. Biological Invasions 5 (3): 261-268.

RECEIVED: June 2010

REVISED: July 2010

ACCEPTED: July 2010

PuBlished ONLINE: September 2010

EDITORIAL RESPonsibility: Simone Chinicz Cohen 